\title{
De reyes providenciales, fidalgos y falsarios. Pelayo de Asturias y las construcciones portuguesas sobre la Restauración de España durante el reinado de Felipe $I V *$
}

\author{
Roberto Quirós Rosado1 \\ Universidad Autónoma de Madrid \\ roberto.quiros@uam.es
}

RESUMEN: Los procesos de gestación de identidades políticas en la península ibérica se fundamentaron en una jerarquía de hitos y protagonistas que, entre la realidad y la leyenda, tomaron cuerpo durante el Medievo y perduraron con vitalidad hasta la Edad Contemporánea. Uno de los sujetos que reiteradamente aparecieron en los anaqueles de la memoria hispana fue «don Pelayo». El oscuro caudillo norteño - bien astur, bien hispanogodo - vadeó los caminos de la historiografía, la literatura política e, incluso, los romances populares y el teatro para convertirse en la piedra angular de los orígenes de la Monarquía de España durante la Edad Moderna. El presente artículo utilizará la figura de Pelayo de Asturias para comprender la construcción de imágenes

* Este estudio forma parte del proyecto «Failure: Reversing the Genealogies of Unsuccess, 16th-19th Centuries» (H2020-MSCA-RISE, Grant Agreement: 823998), dentro de las líneas de trabajo establecidas en el WP4 «Unsuccessful polities, from Empire to Nations, and Internal Relationships», financiado por the European Union's Horizon 2020 research and innovation programme.

En su preparación ha sido fundamental la investigación documental y las actividades científicas vinculadas a una estancia José Castillejo para jóvenes doctores (CAS17-00062), financiada por el Ministerio de Educación, Cultura y Deporte del Gobierno de España y desarrollada en el Centro de História d'Aquém e d'Além-Mar de la Universidade Nova de Lisboa, bajo supervisión del profesor Pedro Cardim.

Siglas utilizadas para denominar los distintos archivos consultados: AGP, Archivo General de Palacio (Madrid); AHN, Archivo Histórico Nacional (Madrid); AHNOB, Archivo Histórico de la Nobleza (Toledo); BA, Biblioteca da Ajuda (Lisboa); BNP, Biblioteca Nacional de Portugal (Lisboa); y RAH, Real Academia de la Historia (Madrid).

1 ORCID iD: https://orcid.org/0000-0003-1773-3254. 
políticas entre aristócratas, genealogistas y tratadistas portugueses durante la crisis de 1640. El estudio sinóptico de sus producciones escritas abrirá nuevas perspectivas para afrontar el estudio del pasado altomedieval durante la eclosión del goticismo, el conflicto entre Felipe IV y João IV y los procesos creativos de argumentación histórica sobre uno de los teóricos padres de las naciones ibéricas y, sobre todo, un modelo de reformación de monarquías en declive ante el espejo de la «restauración de España».

Palabras clave: historiografía; goticismo; Pelayo de Asturias; Portugal; siglo XVII.

On providential kings, fidalgos and falsaries. Pelagius of Asturias and the Portuguese constructions regarding the Restoration of Spain during the reign of Philip IV

ABSTRACT: The process that gave rise to the birth of political identities in the Iberian Peninsula were based on a hierarchy of milestones and protagonists - both real and legendary - which formed during the Middle Ages and remained alive and well into the Modern Age. One of the figures who repeatedly features in the memory of the Iberian Peninsular is "Don Pelayo". The shadowy northern leader - either Asturian or Visigoth-has travelled the roads of historiography, political literature and even popular romances and theatre, to become a cornerstone in the origins of the Spanish Monarchy during the Early Modern Age. This article focuses on the figure of Pelagius of Asturias in a bid to understand the construction of political imagines among Portuguese aristocrats, genealogists and writers during the Crisis of 1640. Synoptic reading of their works offers potential new approaches for studying the history of the Early Middle Ages during the emergence of Gothicism, the conflict between Philip IV and John IV, the creative processes at work in historical argumentation regarding one of the theoretical fathers of the Iberian nations and, above all, a model for reforming declining monarchies, held to the mirror of "Restoration Spain".

KeY WORds: Historiography; Gothicism; Pelagius of Asturias; Portugal; seventeenth Century.

CÓMO CITAR ESTE ARTÍCULO/CITATION: Quirós Rosado, Roberto, «De reyes providenciales, fidalgos y falsarios. Pelayo de Asturias y las construcciones portuguesas sobre la Restauración de España durante el reinado de Felipe IV», Hispania, 80/266 (Madrid, 2020): xxx-xxx. https://doi.org/10.3989/hispania.2020.018.

\section{INTRODUCCIÓN. UN REY GODO EN MUTACIÓN IDENTITARIA}

Pelagi in tumulo vixisti conditus antri / E tumulo Hispanis gloria summa venit. / In tumulo montis mortem contemnis, Ibera / E tumulo surgit quin diuina salus ${ }^{2}$.

2 «Oh, Pelayo, en el túmulo de la cueva viviste, fundado; / desde el túmulo la máxima gloria llegó a las Españas. / En el túmulo del monte desdeñaste la muerte; / cómo no, desde el 
Diego de Benavides, octavo conde de Santisteban y verdadero artífice de la gloria de su linaje merced a una amplia carrera política en el Viejo y el Nuevo Mundo, dedicó un breve epigrama latino al «rege Pelagio» dentro de su notable obra poética. Este opúsculo, el CXV de los contenidos en la primera edición de sus Horce succisivce, se anclaba en un canon compartido en la memoria de nobles y plumistas, de poetas áulicos y escritores religiosos. A comienzos del siglo VIII, el caudillo militar Pelayo había llevado a su primera victoria a las armas cristianas sobre las musulmanas en el seno del monte Auseva. Su triunfo en las montañas asturianas suponía la reversión de la ruina de los hispani, gracias, evidentemente, a una oportuna mediación divina. Constituía, para ministros y escritores políticos del siglo XVII, el inicio del restablecimiento de la Monarquía de España, de la restauración gótica ${ }^{3}$. Sin embargo, tal juicio histórico-providencialista, que asimiló el renacer de los godos a este Fénix coronado, distaba de ser universal a la altura de 1660. Dos décadas antes de la publicación de las poesías de Benavides, Manuel Fernandes Vila-Real no había tenido rubor alguno al tildar de soberanos intrusos a los monarcas medievales de León y Navarra-Aragón. Según este cristão novo portugués, activo impugnador del obispo Juan Caramuel, tales reyes descendían de Pelayo y García Jiménez,

... aclamados uno por los foragidos de Asturias y otro por los malcontentos de las montañas de Xaca, pues ni unos ni otros tenía ligítimo derecho a las tierras de que eran elegidos reyes ${ }^{4}$.

La divergencia de pareceres sobre un personaje que floreciese casi diez centurias atrás - y, todavía en el siglo XXI, no exento de debate historiográficoconstituía una realidad viva en las décadas centrales del Seiscientos. Los exiguos datos que ofrecían los textos altomedievales permitían justificar toda una panoplia de argumentos sobre los orígenes sociales, étnicos y geográficos de Pelayo. La imagen reflejada por el poeta-virrey Santisteban de un líder godo era compartida por numerosos autores castellanos que, incluso, verificaban las noticias que le hacían descendiente directo de la estirpe del rey Chindasvinto.

túmulo emerge la divina salvación ibera», BENAVIDES, 1660: 142-143. Sobre las obras poéticas de don Diego, quien falleció fungiendo el virreinato del Perú, véase LÖFSTEDT, 21/1 (1999): 119-137.

3 A finales de la centuria, Antonio Sebastián de Toledo, marqués de Mancera, o el capellán mayor Pedro Portocarrero recurrieron a la figura pelagiana («primera piedra de este grande edificio») para establecer el origen de las lógicas monárquicas que se encontraban en tela de juicio ante la pujanza militar borbónica y las tensiones por la sucesión de Carlos II. Voto del marqués de Mancera en el Consejo de Estado («En el aposento», 6 de agosto de 1694), RAH, Salazar y Castro, K-42, f. 24r. PORTOCARRERO Y GUZMÁN, 1998: 32 y ss.

${ }^{4}$ VILA-REAL, 1643: 157-158. 
La radical tesis del bragancista luso Vila-Real derivaba de una propuesta ideada por su compatriota António Pais Viegas - a su vez, sobre una postura crítica surgida de la pluma de António de Sousa de Macedo - por la que buscaba la deslegitimación del goticismo imperante a mediados del Seiscientos, corriente entendida como soporte de la concepción castellana del poder monárquico en la España de los Austrias.

La herencia continuista de los visigodos, clave de bóveda de esta corriente historiográfica y literaria, se había fomentado ya en el ciclo cronístico astur de Alfonso III, así como en las obras del arzobispo toledano Ximénez de Rada y Alfonso X, alcanzando las genealogías legitimadoras del poder Trastámara 5 . La asunción casi universal de la herencia goda sobre las formas políticas que sustentaban la corona de Castilla se trasluce en los tratadistas de su nación y los que trabajaran al servicio de la casa de Habsburgo durante el siglo XVI ${ }^{6}$. La justificación del presente a través del cevum pasado era, para entonces, materia común en todas las monarquías y repúblicas europeas. De los tiempos pretéritos, especialmente los de Roma y los reinos germánicos, surgían los elementos que daban razón de ser al sistema constitucional o al poder de los soberanos ${ }^{7}$. Junto al tacitismo importado en la península ibérica a finales del Quinientos, el recurso a las vindicaciones góticas iría construyendo una serie de arcanos identitarios bien sobre monarcas, bien sobre acontecimientos políticos y militares que fluirían de forma ambivalente entre las elites regnícolas y los ministros del rey de España ${ }^{8}$.

Tras breves alusiones en las obras cronísticas de tiempos de los Reyes Católicos o en historiógrafos tan divergentes como Florián de Ocampo y Esteban de Garibay ${ }^{9}$, Pelayo comenzó a ganar espacio histórico-literario en las obras de Ambrosio de Morales. El humanista andaluz focalizó su atención sobre el caudillo godo en los dos últimos volúmenes de su Corónica general de España (1577 y 1586). El punto de partida del cronista cordobés pasaba por demostrar la continuidad «con gran gloria de España, desde don Pelayo hasta agora, que nunca los castellanos besamos mano de rey que no la uviéssemos besado de su padre $»^{10}$. La figura pelagiana como artífice de la monarquía castellana no había

5 CARBÓ GARCÍA, 2015.

${ }^{6}$ RÍOS SALOMA, 28 (2005): 389-391.

7 GEARY, 2002. VILLANUEVA LÓPEZ, 2004. BENIGNO y BAZZANO, 2006. CARDIM, 2014: 55. FERRO, 2017. Igualmente, es preciso recordar la crucial obra de HOBSBAWM y RANGER, 1983.

${ }^{8}$ Sobre la implementación paulatina del tacitismo en los reinos hispanos, véase MARTÍNEZ BERMEJO, 2010. Para los discursos y debates identitarios altomodernos de los orígenes de España de la transición de la Antigüedad al Medievo, véase FERNÁNDEZ ALBALADEJO, 2005.

9 OCAMPO, 1553: LXXIIv-LXXIIIr. GARIBAY, 1571: 382-385.

${ }^{10}$ MORALES, 1577. 
sido puesta en duda desde la plenitud del Medievo, pues su imagen providencialista proyectaba un halo de asenso divino a la legitimidad dinástica de sus monarcas más allá del contrato político establecido entre rey y vasallos. El infante Pelayo hacía su entrada en la Corónica al haber escapado de las manos de su pariente Witiza, artero y violento, quien no pudo quitarle los ojos o la vida al refugiarse «en su tierra de Vizcaya» y, de allí, peregrinar a Jerusalén, siempre según los relatos populares y las leyendas piadosas de los bordones de Arratia. Tras regresar al reino godo y después de la derrota de Guadalete, el caudillo escoltó al arzobispo Urbano hacia Asturias para la «guarda y defensa» de las reliquias toledanas. Desde allí, lograron escapar a la «destruyción de España», viviendo ellos y sus acogidos en libertad,

... y ellos eligieron presto entre sí al infante por rey que los governasse, y en religión y en govierno y aprovechamiento de la tierra y su lavor y grangerías, hazían a su voluntad, como antes de la destruyción solían ${ }^{11}$.

La figura emblemática de los «christianos libres», dotados de capacidad de elección de sus cabezas militares y ovejas de prelados vagantes, no impedía a Morales valorar la legitimidad del dominio godo sobre la naciente monarquía asturiana. Idéntica reflexión aportó paralelamente un oscuro burgalés, vecino de Arroyo de Muñó, Julián del Castillo. La Historia de los reyes godos (1582), dedicada a Felipe II, no había nacido de otra intención que la de mostrar la herencia sanguínea de los soberanos germanos «que vinieron de la Scitia de Europa» hasta España, derrotando a los romanos y creando una monarquía nueva que se perpetuara por los siglos hasta los tiempos del Rey Prudente. Pelayo constituía, al igual que para Morales, el nexo entre los viejos y los tiempos modernos tras la venida de los moros. Descendiente de los reyes visigodos y de un preclaro «nativo hispano antiguo nobilíssimo», fue alzado por sus hombres, godos e hispanos, unidos ante una causa providencial, como «rey de los godos y España (...) que le pertenecía por la propiedad y directo dominio o derecho señorío» ${ }^{12}$.

La estirpe germánica y el motor confesional convergerían en la nueva narración que Ambrosio de Morales hiciese de Pelayo y Covadonga en el decimotercer capítulo de la Corónica (1586). Para ello, evocaba sus lecturas de crónicas medievales de prelados gallegos, leoneses y castellanos, bien el expurgo de otras evidencias materiales, toponímicas, naturalistas y arqueológicas. La negación de cualquier validez a las obras de sus coetáneos se halla, de hecho, en la inexistencia de cualquier vinculación ni directa, ni indirecta a la obra de Julián del Castillo. La esencia apocalíptica de la pérdida de España y su consecuente

\footnotetext{
${ }^{11}$ MORALES, 1577: 198r, 205v-206v.

12 CASTILLO, 1582: LIXv-LXr.
} 
restauración ya había articulado el curso de la semblanza biográfica en 1577, por lo que ahora el afán del cronista general sería ofrecer una vívida imagen y cronología de los sucesos conducentes a la proclamación militar del soberano, los primeros combates contra «Tarif y a sus moros principales» y, finalmente, la batalla de Covadonga. Pese a su experiencia visual de la cueva asturiana, los abultados números de combatientes y los sucesos milagrosos evocados por las auctoritates consultadas transmitirían al público lector una narración inverosímil, pero paradigmática, de la misión sagrada de Pelayo y sus acólitos. La proyección literaria de los textos medievales tendría cabida, asimismo, con la transcripción de las conversaciones que - según los apócrifos textuales - mantuvieron Pelayo y el prelado Oppas. Incluso, la memoria de las poblaciones locales constituyó una fuente esencial en la narrativa ambrosiana, caso del reflejo de las creencias «como cosa muy cierta entre ellos que al rey don Pelayo se le apareció el día de la batalla una cruz en el cielo», argumento poco transitado hasta entonces y que tomaría vigor durante el último tercio del siglo XVII ${ }^{13}$.

Leyendas populares e imaginaciones de los viejos cronistas alcanzaron, merced a la indiscriminada difusión impresa de la Corónica general, un rango de fidelidad histórica hasta entonces nunca registradas. La vigencia del relato de Morales oscureció las siguientes descripciones historiográficas que reprodujeron en mayor o menor medida la autoridad del cronista cordobés, sin cuestionamiento crítico alguno. Las bases de la vida de Pelayo quedaban fijadas de forma inveterada, fosilizada, para el resto del Quinientos y el siglo XVII, como demuestra lo sintético de su reflejo en la obra de Juan de Mariana ${ }^{14}$.

El periplo de Pelayo por las crónicas humanistas culminó en nuevos horizontes y públicos alternativos. La consideración del soberano de Asturias como «el postrer godo de España» en una comedia homónima de Lope de Vega, probablemente coetánea al festejo de las bodas de Felipe III y Margarita de Austria en Denia (1599), dio impulso a su asimilación como fundador de la Monarquía de España, tanto en los mensajes políticos implícitos en la famosa comedia como en su articulación literaria ${ }^{15}$. Para Lope, la catástrofe de los godos y su rey Rodrigo ante las huestes musulmanas en Guadalete era la condición sine qua non para el nacimiento de una nueva España a través del triunfo providencial del noble visigodo Pelayo en Covadonga, que centraría el tercer acto de la representación:

Para bien amanezca / el Sol Español / bendígale España, / y guárdele Dios. / El Sol de Pelayo, / gran restaurador / de Asturia y Galicia, / Castilla y León... ${ }^{16}$.

\footnotetext{
${ }^{13}$ MORALES, 1586: 1r-9v.

14 MARIANA, 1601: 391-394, 402, 404, 416-429.

${ }_{15}$ Para un detenido estudio literario e histórico de los sucesos de Denia, véase VEGA Y CARPIO, 2004.

${ }^{16}$ VEGA Y CARPIO, 1617: 136v. Sobre la relevancia de la temática histórica en la construcción imaginada del poder monárquico de las comedias de Lope de Vega, véase CARREÑO, 2003.
} 
La inauguración del reinado del tercer Felipe, el Sol que se disponía a brillar merced a su justicia católica, demostraba la vigencia política de la materia pelagiana. Similar intención a la del Fénix de los Ingenios manifestaron Alonso López, Pinciano, doctor de la emperatriz María de Austria y poeta aficionado, y el extremeño Cristóbal de Mesa. Mientras el primero usó los modelos de Torquato Tasso para componer El Pelayo (1605) sobre la base de leyendas piadosas de la peregrinación del caudillo a Jerusalén y su victoria en Covadonga ${ }^{17}$, Mesa proyectó en su epopeya El Pelayo, o restauración de España (1607) la mímesis entre el godo con la dinastía reinante, augurando cómo

Tú Filipe, del rey Pelayo el santo, / imitando el valor y el zelo pío, / serás qual el restaurador segundo, / a dos Españas aumentando un mundo ${ }^{18}$.

Los epítetos de Lope, Pinciano y Mesa diferían sensiblemente de los que compuso paralelamente Diego Suárez. Este soldado asturiano de los presidios de África dio a la imprenta complutense de Juan Gracián Tres romances de Asturias de Oviedo (1607), cuya primera composición trataba de la elección del rey Pelayo. Mientras la corriente general de cronistas y literatos afirmaba el origen godo del monarca, Suárez no dudó en afirmar que su elección no se había hecho por su sangre, en ningún caso gótica, sino por «los concejos de la nación asturiana para elegir caudillo y bien defender su patria $\rangle^{19}$.

La siguiente década prosiguió demostrando la vigencia de las tesis legendarias sobre el soberano altomedieval, ya no solo en la corte del rey Felipe y sus aledaños universitarios, sino en otros reinos peninsulares, como Aragón y Portugal. Luis Vélez de Guevara, con su poco conocida comedia El alba y el sol (circa 1613), y los cantos trágicos del secretario aragonés Juan Yagüe de Salas, titulados Los amantes de Teruel (1616), dieron buena cuenta de la popularidad adquirida por la memoria del rey Pelayo entre creadores y auditorios diversos en toda la geografía peninsular ${ }^{20}$. Uno de los ejemplos más relevantes de esta difusión temática serían los nada inocentes versos con los que la poetisa portuguesa Bernarda Ferreira de Lacerda abriese su epopeya Hespaña libertada (1618):

La libertad de nuestra Hespaña canto, / y hazañas de aquel godo valeroso, / que con ánimo osado y zelo santo / la fue quitando el jugo trabajoso. / Y los hechos también dignos de espanto, / y de sublime verso belicoso, / que hizo la hespañola gente fuerte / triumphando del tiempo y de la muerte ${ }^{21}$.

\footnotetext{
17 LÓPEZ, 1605.

18 MESA, 1607: 178r.

19 SUÁREZ, 1607.

20 YAGÜE DE SALAS, 1616.

${ }^{21}$ LACERDA, 1618: 1r
} 
A través de obras teatrales, poemas heroicos y cordeles populares, tales artefactos escritos consumaron la unión entre la historia gótica y los albores del reino astur. La intencionalidad política de estas obras y opúsculos quedaba demostrada en los nexos existentes con tres acontecimientos fundamentales de sus reinados: el enlace real (1599), la expulsión de los moriscos (1609-1613) y los debates lusos sobre el viaje de su soberano a Lisboa (1619). Paulatinamente, la batalla de Covadonga y la elección del primer monarca de Asturias se situarían en el epicentro de la identidad de la monarquía de Felipe III, bajo cuyo reinado se había proyectado la Pax Hispanica como medio de conservación activa del inmenso patrimonio dinástico de los Habsburgo y en la cual el factor confesional — común justificación de las políticas austriacas - teñía la mayor parte de los actos políticos de la monarquía ${ }^{22}$.

\section{Pelayo y las historiografías portuguesas en la monarquía del Rey Planeta}

La muerte de Felipe III en 1621 y la subida al trono de Madrid de su joven heredero, Felipe IV, provocaron una cesura no solo en los métodos de gobierno de una monarquía universal, consolidando el valimiento - ahora del círculo Zúñiga/Guzmán—, sino también en los medios de propaganda, ante el horizonte bélico que se cernía sobre las tierras del nuevo monarca. Bajo la protección del conde-duque de Olivares, las plumas teñidas estudiadas por José María Jover Zamora y Richard Kagan utilizaron sin rubor los recuerdos del pasado gótico para fortalecer la pujanza de la corona, asimilándola al imperium que los reyes de sangre germánica ejercieron durante siglos sobre las cenizas de Roma. Las nuevas historias políticas a cargo de Joseph Pellicer, Virgilio Malvezzi o el conde de la Roca - incluso, algo más adelante, Diego de Saavedra Fajardo- equipararon la nación española, el poder de las elites castellanas $\mathrm{y}$, dentro de ellas, su justificación como herederas de la prosapia germánica. No era arbitrario que los Guzmán fuesen parte intrínseca de estas parentelas godas, ni tampoco que auspiciasen la difusión indiscriminada de tales mensajes etnohistóricos ${ }^{23}$.

Los discursos goticistas generados por el olivarismo cortesano, que culminarían en la década de 1640 con el mencionado Saavedra Fajardo y su Corona góthica, provocaron una abierta contestación por parte de otras elites aún felipistas. Sería en los reinos periféricos a Castilla donde tomase cuerpo a lo largo de los siguientes decenios una apuesta hacia otras naciones originarias, no necesariamente godas, como sustrato directo de sus privilegios y fórmulas de

22 GARCÍA GARCÍA, 1996.

23 JOVER ZAMORA, 2003. KAGAN, 2012. 
gobierno monárquico: el legendario reino de Sobrarbe, los aragones pellicerianos y, en el occidente peninsular, el Portugal suevo ${ }^{24}$.

El continuum asturiano, en tanto epílogo del dominio visigodo sobre la península, había consolidado en Portugal una imagen canónica de Pelayo como uno de sus guerreros «levantado por rey de Espanha», según había afirmado fray Bernardo de Brito en $1609^{25}$. Para ello, el benedictino había hecho suyas conocidas fuentes del Medievo y las obras maestras de la cronística castellana del siglo precedente. En la profusa descripción de los orígenes familiares, juventud y hechos de armas del soberano de las Asturias quedaba patente la huella de Morales y Julián del Castillo, aunque introdujo otras lecturas alternativas, caso de La verdadera hystoria del rey don Rodrigo, traducida por el morisco Miguel de Luna (1592) que, a la postre, servirían de materia prima a los escolios de Rodrigo Mendes Silva.

El Pelayo portugués descrito por Brito y, diez años más tarde, redefinido en un poético héroe español por Bernarda Ferreira de Lacerda volvió a ser objeto de comentario en 1631. La polémica corografía de António de Sousa de Macedo (1606-1682) Flores de España, excelencias de Portugal cargó su tinta en contra de la imagen universalista de la Hispania goda, tal y como se proyectaba desde Madrid, y censuró sin tibieza la premisa de la sucesión de los reyes de Castilla y León «como verdaderos descendientes y herederos de los reyes godos y de don Pelayo»y, por ende, «el legítimo señorío de toda España». Macedo, jurista y firme defensor del recuerdo suevo en el reino luso, dirigía sus invectivas contra la castellanización de las historias hispanas, no tanto a dañar la figura heroica del «rey primero de las Asturias». Este, que contaba con la protección divina para su causa, revestía importancia ad futurum no por su sangre u origen, sino por la capacidad de transmutar «todos los favores que comunicó a otras naciones», entre ellas, la portuguesa y la aragonesa. De hecho, la intervención divina en los milagrosos sucesos de Covadonga hacía entroncar el favor del Cielo a su monarquía como siglos después, en Ourique, sucediese con el fundador del reino de Portugal, Afonso Henriques ${ }^{26}$.

La crítica, aunque de soslayo, comenzó a socavar la general asunción historiográfica de la translación gótica del reino de Toledo hacia la naciente corona

${ }^{24}$ CARDIM, 2014: 54-55, 140-141, 197. FLORISTÁN IMÍZCOZ, 27 (2007): 59-81. QUIRÓS ROSADO, 2018.

25 BRITO, 1609: 223v, 258r-259r, 283v-287r.

${ }^{26}$ SOUSA DE MACEDO, 1631: 34r-v, 36v-37r, 91v. António de Sousa de Macedo volvió a recurrir a Pelayo años más tarde. En su Lusitania liberata, uno de los más difundidos tratados de justificación de la elevación a la dignidad regia del duque de Bragança como João IV, el autor lo tomó de ejemplo para tratar la sucesión dinástica de las mujeres entre los Asturienses (no los godos), la consecuente sucesión de los reyes de Castilla por vía femenina y la justificación de que el astur había constituido «novum maioratum diversum a Regno Gothico», siguiendo el parecer del jesuita castellano Luis de Molina. SOUSA DE MACEDO, 1645: 254-255. 
de Asturias. Las reglas del juego político ibérico cambiarían en pocos años. De la argumentación de Sousa de Macedo otros compatriotas tomarían munición propagandística en las nuevas disputas que tendrían lugar con las armas y el cálamo a partir de diciembre de 1640 . Como otros elementos clave en la legitimación de la soberanía de Felipe IV sobre Portugal, el recurso a Pelayo obligaría a requerir sujetos que salvaguardaran su imagen de patriarca de España y proyectasen su legado como providencial restaurador y reformador de monarquías en descomposición.

La conspiración nobiliaria portuguesa del 1 de diciembre de 1640 acabó con la vida del secretario Miguel de Vasconcelos y franqueó la sustitución del gobierno virreinal de la duquesa de Mantua, Margarita de Saboya, por una corona propia. Si bien la continuidad de la guerra con Francia en tierras catalanas tras el Corpus de Sang y el impacto de las recientes catástrofes navales de las Dunas, Guetaria, Laredo y Santoña socavaron el crédito político del conde-duque de Olivares, la caída de Lisboa en manos de los fidalgos que proclamaron rey al duque de Bragança, João IV, determinó el broche del annus terribilis para el Rey Planeta y su valido. La casuística de la guerra viva o lo impredecible de un levantamiento popular —el catalán - mediatizado por elites disidentes diferían de lo acaecido en Portugal, donde las impopulares medidas implementadas por Vasconcelos y su patrón en Madrid, Diogo Soares, laminaron las redes de fidelidad al soberano Habsburgo desde años atrás ${ }^{27}$.

El mayoritario apoyo a João IV dado por la nobleza, el clero y el estamento popular no fue suficiente a la hora de articular la defensa del restaurado reino de Portugal bajo los auspicios de la casa de Bragança. La pugna papelística rápidamente dotó de pólvora tintada y armas de cáñamo y pluma al conflicto militar. Uno de los primeros justificadores de la causa juanista fue António Pais Viegas (floruit [fl.], 1640-1650). Autor de Principios del reyno de Portugal (1641), realizó una genealogía del fracaso gótico y de su trasunto habsbúrgico a la hora de unificar a los pueblos y naciones de la antigua Hispania ${ }^{28}$. Estableciendo un tácito paralelismo entre los soberanos visigodos y los Felipes, los primeros «perdieron como ganaron» el reino ibérico, pues el mero ejercicio de la violencia como fórmula de imposición revirtió en su caída por idénticos medios. Para Viegas, los siguientes reyes cristianos «fundaron nuevos y distinctos reynos, no continuaron el passado», es decir, «qualquiera príncipe christiano pudo en ella intentar conquistas»».

La negación taxativa de cualquier nexo de continuidad entre la monarquía toledana y los nuevos reyezuelos cobijados en las montañas del Norte anularía los peregrinos intentos de sus descendientes - es decir, la casa de Austria- para

27 BOUZA, 9-10 (1993): 17-28. VALLADARES, 15 (1995): 103-136.

${ }^{28}$ Las siguientes referencias sobre Pelayo por parte del propagandista de João IV de Bragança, en VIEGAS, 1641: 25v-27v, 34v-36v. 
justificar su imperium peninsular. Dado que «el derecho de los godos era acabado», Pelayo de Asturias, los futuros reyes de Navarra y «los franceses por Cataluña» habían dado inicio a una nueva era de construcción de consensos y soberanías. El recuerdo a la penetración carolingia sobre los Pirineos Occidentales y de los monarcas navarros no era extemporánea para el polemista portugués. La alianza que firmasen João IV y Luis XIII de Borbón - rey de Francia y de Navarra y nuevo conde de Barcelona - parece estar nuevamente en el fondo de las afirmaciones políticas de Viegas. Invalidando por medio de las crónicas y el derecho cualquier identificación de los descendientes de los reyes de Asturias y León con «sucessores de la corona goda», era conveniente potenciar la idea de una península medieval completamente ajena a cualquier opción de dichos soberanos «al señorío de Hespaña».

La imagen pelagiana configurada por António Pais Viegas no distaba de la que generase Sousa de Macedo. El caudillo asturiano y sus sucesores, «phénices renacidos de sus cenizas [del reino de Toledo]» solamente se hicieron dominadores no de toda España, sino de las tierras que fueran ganando por medio de las armas. Pelayo, duque de Cantabria como sus coetáneos Pedro y Eudo de Gascuña, era nieto del rey Chindasvinto, pero nunca había tenido acción a recibir la corona de los godos. Su levantamiento no habría sido consecuencia directa de la derrota del rey Rodrigo, sino de agravios personales del gobernador de Gijón, Munuza, hacia su hermana, a lo que sumara su conversión en la última esperanza del pueblo cristiano dadas sus heroicas dotes naturales. La huida de Pelayo a Galicia y la victoria en Covadonga gestaron las bases de su potestas. En ningún caso había llevado a cabo una empresa confesional, aunque interviniese la providencia divina. Su éxito principiaba una monarquía nueva, pero no exclusiva. La proclamación del legendario Garci Ximénez en Sobrarbe y las conquistas francas en Cataluña ayudarían a justificar, en 1641, las soberanías de reciente aparición y eliminar, por fin, la hegemónica narrativa goticista $^{29}$.

Mientras en la Lisboa bragancista se relativizaba la imagen de unos orígenes regios compartidos desde los albores del Medievo, en Madrid se vivió un fortalecimiento de las tesis políticas tendentes a sustentar la noción de continuidad y legitimidad del dominio habsbúrgico en Portugal. La obediencia a Felipe IV fue la tónica dominante entre la fidalguia asentada en la corte española, al igual que entre los mandos militares portugueses de Cataluña y Flandes y las redes financieras de asentistas y arrendadores, estrechamente ligados al sistema clientelar de los Guzmán-Haro. Su futuro, en particular el de los títulos y señores, dependería en adelante de la munificencia del soberano austriaco y de su capacidad de permanecer activos en el servicio de las armas en ejércitos y presidios, en

29 Sobre los lazos diplomáticos franco-portugueses durante la Restauração, véase PRESTAGE, 1925. 
tribunales privativos - como la Junta de Portugal establecida en 1642 - o en las casas reales. El levantamiento del reino luso supuso paralelamente una oportunidad para medrar y erigirse como cabezas de su nación, denotando una acrisolada lealtad, como harían en 1641 un numeroso grupo de miembros de la casa de Mascarenhas al pasarse en barco a Andalucía. El flujo de memoriales y de obras justificativas de sangre y méritos se convirtió, de este modo, en un continuum durante las más de dos décadas que duró el conflicto hispano-portugués ${ }^{30}$.

La esperanza de una exaltación sociopolítica y el propio estatus ocioso de alguno de los señores lusos tuvieron eco en el ámbito de la historiografía y del cultivo de la memoria aristocrática. Bien como manuscritos nunca editados, bien en forma de libros o tratados publicados en las imprentas madrileñas, los nobles felipistas tomaron la pluma y el papel para dar corporeidad al pasado de sus linajes y a las historias de los orígenes de la Corona a la que servían en tierra extraña. Félix Machado de Silva, marqués de Montebello (circa 1595-1662), Jerónimo de Ataíde, marqués de Colares († 1669), Duarte de Albuquerque Coelho, conde de Pernambuco y marqués de Basto (1591-1658), y António Soares de Alarção, primogénito de los marqueses de Turcifal y condes de Torres Vedras (fl. 1656), conformaron la mayor parte de este sector de escritores nobiliarios que, de forma alternativa, configuraron en diversos escritos la génesis y evolución de la Monarquía de España y sus reinos conformantes, así como la imagen lusitana de las raíces histórico-legendarias de soberanos y aristócratas.

La ausencia de fuentes correlativas a la confección del opus de los señores exiliados, tales como correspondencias no tanto políticas sino familiares o «culturales», obliga a desentrañar las causas conducentes a la creación de tales relatos. Particular atención merecen las semblanzas biográficas de los reyes de Asturias a cargo de Colares y los Elogios a los reies de España que debiese esbozar o, al menos, supervisar ( circa 1643) ${ }^{31}$, y los dos compendios de Pernambuco sobre la sucesión dinástica de los monarcas de España y, específicamente, Portugal (Compendio de los reyes de España desde Pelayo asta el rey don Felipe 4 $4^{\circ}, 1647^{32}$; Compendio de los reyes de Portugal, 1652 ${ }^{33}$ ). Por un lado,

${ }^{30}$ BOUZA, 20 (1994): 83-104. Asimismo, para profundizar en torno a la «corte de los portugueses», véase VALLADARES, 1994: 163-235; 1998. TERRASA LOZANO, 2009. Gran parte de la nobleza y de los juristas leales a Felipe IV se vinculó al servicio de la Junta y posterior Consejo de Portugal. LUXÁN MELÉNDEZ, 8-9 (1987-1988): 61-86.

31 Jerónimo de Ataíde, Semblanzas de los reyes de Asturias, mss., Madrid, post. 1643, BA, 51-IX-12: 126r-130v. Elogios a los reies de España, 1643, BA, 51-IX-12: 131r-134v.

${ }^{32}$ Duarte de Albuquerque Coelho, Compendio de los reyes de España desde Pelayo asta el rey don Felipe $4^{\circ}$, mss., Madrid, 1647, BNP, Cod. 904. Su cronología de escritura se amplió hasta 1657, por lo que existen modificaciones del propio conde de Pernambuco a los capítulos iniciales de su obra y añadiduras en el colofón del tratado.

${ }_{33}$ Duarte de Albuquerque Coelho, Compendio de los reyes de Portugal, mss., Madrid, 1652, BNP, Pombalina, 140. 
el métier d'historien de los autores nobiliarios portugueses diferiría del de sus compatriotas con una carrera profesionalizante en el ámbito genealógico, cronístico o de edición literaria, caso de Manuel de Faria e Sousa (1590-1649) o Rodrigo Mendes Silva (1606-1670). Ninguno de los cuatro mencionados fidalgos escribiría por cuenta ajena, ni vendía el producto de su memoria a terceros, fuesen otros nobles o corporaciones. Su supervivencia en el Madrid de Felipe IV no dependería de la valía de lo escrito, sino de la fama que emergiese de tales producciones literarias o, sobre todo, de argumentos de autoridad que moviesen la gracia soberana en su dirección e intereses.

En relación a la búsqueda de la intrahistoria originaria de los reinos y señoríos ibéricos, dos de los mencionados señores, Machado de Silva y Alarção desarrollaron la temática gótico-astur por una vía colateral, asimilando o construyendo entronques falsarios de familias nobiliarias (los Sandoval y los Ceballos) con los compañeros de armas de Pelayo en sus memoriales y relaciones genealógicas ${ }^{34}$. Por su parte, Ataíde y Alburquerque anclaron sus obras por medio de relaciones y glosas iniciadas en los ecos de la destrucción de la monarquía gótica. Sus escritos los convertían en herederos de la tradición historiográfica de Brito y Faria e Sousa y, a su vez, en corifeos portugueses de las historias políticas deudoras de los ya citados Virgilio Malvezzi, el conde de la Roca y Diego de Saavedra Fajardo. No obstante estas divergencias, los cuatro aristócratas compartían elementos comunes en su confección de tratados y escritos menores. En primer lugar, desarrollaron un cariz vindicativo de las lealtades lusas a la corona del rey Felipe. En segundo, traslucían una intencionalidad política y moralizante; y, por último, desplegaron argumentaciones abiertamente opuestas a las tesis particularistas de los autores fieles a la casa de Bragança.

La erudición diletante no produciría textos de metodología o estructura novedosas $^{35}$. El encorsetado modelo de memoriales genealógicos y de listados de soberanos y dinastías posibilitaba, aun con todo, cierto margen de maniobra a los autores. En el caso de Pernambuco, sus dos lacónicos compendios denotan un afán comparativo en el ámbito de la naciente cronología para fundamentar de manera crítica la sucesión de acontecimientos políticos que surgieron de los providencialistas tiempos de Pelayo. Por contra, Jerónimo de Ataíde adecuó sus apologías pelagianas con argumentos personalistas y discursos ficticios de talante político-confesional. Entraña más dificultades establecer una arqueología de sus bases historiográficas. El uso de manuscritos consultados en la corte de Madrid se reduce a lo testimonial. Para la materia pelagiana, solo Félix Machado de Silva reconoció haber consultado documentación original en la biblioteca del condestable de Castilla, evidentemente monumenta tardomedievales. Otras referencias

\footnotetext{
${ }^{34}$ MACHADO DE SILVA, 1642: 117-118. SOARES DE ALARÇÃO, 1656: 103.

35 REY CASTELAO, 27 (2007): 35-58.
} 
sí que permiten establecer los vínculos librarios con autoridades canónicas como Ambrosio de Morales y Juan de Mariana, si bien ciertos falsarios - Tomás Tamayo de Vargas - y eruditos foráneos pueblan las citas del hijo mayorazgo de Turcifal. Colares y Pernambuco parecen haberse servido de nombres de cierto predicamento, en tanto modelos constructivos para las obras de ambos fidalgos. El recurso a Julián del Castillo y la estructura de tablas dinásticas de Esteban de Garibay habrían de mencionarse en este plano hipotético. Por último, si dos escritores coetáneos sirvieron de ejemplo para las plumas señoriales, estos fueron Manuel de Faria e Sousa y, ante todo, Rodrigo Mendes Silva.

Deteniendo el análisis en el tópico de la restauración de España, la sombra de este prolífico cronista judeoconverso es manifiesta ${ }^{36}$. Mendes Silva, natural de Celorico (en la raiana Beira), se había afincado en la corte de Madrid siendo protegido del poderoso secretario Diogo Soares. Como inicio de una prolija cantidad de tratados políticos, corográficos y genealógicos, el Catálogo real de España se publicó en 1637, siendo nuevamente editado y reformulado en 1639 y 1656, y experimentará una amplísima difusión por los canales intelectuales de la monarquía. El alcance de la obra y su impacto cultural influyeron decididamente en la composición de otras obras similares de autores coetáneos, en particular, los titulados exiliados tras 1640. Por un lado, a través de sus capítulos iniciales se proyectaba el armazón genealógico goticista de los orígenes de Pelayo ${ }^{37}$. Las fuentes históricas fidedignas, base de las realizaciones de fray Bernardo de Brito u otros cronistas del siglo XVI, ya no ocupaban un lugar preferencial en su construcción imaginaria del soberano. Por el contrario, se aunaban sin criterio alguno las crónicas de Morales, Mariana o Jerónimo de Blancas, las obras de fray Prudencio de Sandoval y Pedro Salazar de Mendoza, los falsos cronicones de Jerónimo Román de la Higuera y textos manuscritos lusitanos conservados en Alcobaça, inclusos los del «moro Alcobacín», es decir, Miguel de Luna. Junto a ello, tradiciones e ideas de propio cuño servirían a Mendes Silva para justificar los orígenes y evolución política de la Corona austriaca sobre los fundamentos históricos de la caída del reino godo y su restauración pelagiana. El halo divino en los sucesos del 711 posibilitó al cronista la inclusión de comentarios apocalípticos y censuras contra los excesos de los gobernantes, tan desarrollados por los autores políticos coetáneos:

¡O gran Dios, que tal es tu poder! Y cómo sabes quándo quieres castigar, echar por el suelo con un soplo todas las fuerças humanas y deshazer nuestros aprestos, prevenciones, ardides, defensas y reparos, confundir nuestro saber y entender, trabucándolo todo según conviene a tu justicia y a tu misericordia.

\footnotetext{
${ }^{36}$ RÉVAH, 67/3-4 (1965): 225-252. GUILLÉN BERRENDERO, 30 (2014): 35-60.

37 SILVA, 1639: 31r-32r, 35r-39r.
} 
De las enseñanzas extraídas de la derrota de Guadalete emergía la figura de Pelayo. Descendiente de Chindasvinto y su supuesto hijo Favila, el infante había de ser «glorioso restaurador de España y progenitor de sus católicos reyes». Frente al apasionado Rodrigo, el joven godo aparecía reuniendo a la nobleza retirada a los montes norteños y poniendo límite, así, a los funestos destinos de la monarquía de Toledo. No había novedad en escoger a Pelayo como sujeto paciente para la fijación de un canon de virtud política, como ya se habían encargado los cronistas quinientistas y los escritores del tiempo de Felipe III, pero de esta forma quedarían entroncadas las corrientes tacitistas y goticistas.

Retornando a los portugueses titulados, el ciclo cronístico de Colares y Pernambuco evoca una marcada dependencia respecto a los modelos tipificados de historias regias. En el artefacto cronístico-político acuñado por Mendes Silva, el pasado quedaba tipificado como un objeto discursivo presentista. Si bien Ataíde siguió la estela del cristão-novo por medio de la inclusión de falsos discursos moralizantes, ambos fidalgos coincidieron en analizar y contrastar datos, lugares comunes y errores temporales que habrían de ser depurados a favor de un sistema narrativo más directo. Mientras Albuquerque Coelho desarrollaba una original disquisición cronológica para delimitar batallas y reinados, la materia genealógica que trató de censurar también fue el principal objeto de crítica de dom Jerónimo, el cual arremetió contra quienes tachaban a Pelayo de hijo natural del duque de Cantabria: por contra, sería un infante godo descendiente de reyes de Toledo, y emparentado por vía matrimonial con la familia del erudito san Ildefonso. La fuerza de la sangre era un argumento válido para acallar cualquier duda sobre la legitimidad de su filiación y, por ende, de su soberanía. Los cronistas no se habían puesto todavía de acuerdo, a decir de dom Duarte, sobre si fue o no alzado rey por la aclamación de sus seguidores. Los argumentos del padre Mariana y sus epígonos habrían de tomarse por canónicos en su narración, pues «hazen mención del principio del reynado de don Pelaio desde el perdimiento del rey don Rodrigo», lo que aseguraba un continuum sin cesura de la monarquía gótica ${ }^{38}$.

Pese a contarse con tales testimonios intratextuales, la falta de cualquier prólogo o justificación de las obras impide conocer la causa directa de esta proliferación literaria. En el exilio madrileño, la creación historiográfica y literaria de los portugueses felipistas se había multiplicado exponencialmente respecto a las décadas de unión dinástica. Junto a la producción de cronistas, poetas y dramaturgos, se escribieron y difundieron textos teológicos sobre la razón de Estado o panfletos de temática variada ${ }^{39}$. En muchos casos, el factor genealógico y la

${ }^{38}$ Duarte de Albuquerque Coelho, Compendio de los reyes de España desde Pelayo asta el rey don Felipe $4^{\circ}$, mss., Madrid, 1647, BNP, Cod. 904: 2.

${ }_{39}$ Sobre la literatura política generada al albur de la crisis de 1640, la caída de Olivares y el valimiento encubierto de Luis Méndez de Haro, véase FERNÁNDEZ ALBALADEJO, 2009: 303-393. 
narración de servicios de particulares y sus parentelas monopolizaban la obra de los más demandados, caso de Rodrigo Mendes Silva. La aparición del Nobiliario del conde de Barcelos, en versión crítica a cargo de Manuel de Faria -integrando sus comentarios genealógicos junto a los del marqués de Montebello y Álvaro Ferreira de Vera-, tendría como objetivo primordial la salvaguarda de la memoria nobiliaria portuguesa, derivando alguno de sus argumentos de las progenies de ciertos caballeros godos que franquearon a Pelayo en la cueva del monte Auseva ${ }^{40}$. Del propio Faria e Sousa constará una breve semblanza de los orígenes y los actos pelagianos, dado que tras su aclamación, el rey logró la restauración hispana al protagonizar «la tragedia más triste que se representó en el Teatro del Mundo», es decir, para sus derrotados enemigos musulmanes ${ }^{41}$. Los manuscritos de la Europa portuguesa que completasen el Epitome de las historias portuguesas (1628) se destinaron a glosar un pasado reciente, el de Portugal, como punta de lanza de un imperio cristiano en las tierras de Além-Mar, el cual había sido originado en los oscuros años iniciales del siglo VIII desde las ruinas del reino de Toledo.

El perfil de los dos fidalgos apasionados por la figura pelagiana era diametralmente opuesto al de Mendes Silva, conocido cristiano nuevo, y el de Faria e Sousa, caballero de la Orden de Cristo y antigua hechura de la casa de Moura ${ }^{42}$. Duarte de Albuquerque Coelho era un exponente de la antigua nobleza donataria de Brasil, por lo que había sufrido directamente el impacto de las invasiones neerlandesas durante las décadas de 1620 y $1630^{43}$. Conde de Pernambuco por privilegio de Felipe IV, se mostró fiel a su causa y, junto con su único hijo varón, se afincó en Madrid. El ocio de dom Duarte fue conllevado con la confección de las Memorias diarias de la guerra del Brasil, abiertamente censuradas por el mencionado secretario Diogo Soares y que tardaron más de una década en ser impresas, ante las controvertidas críticas sobre la política americana del círculo de Olivares ${ }^{44}$. La muerte de su hijo en el frente de Cataluña le reportó su inserción en la Casa de Borgoña como gentilhombre de Cámara sin ejercicio. Junto a ello, accedió a la Junta (y posterior Consejo) de Portugal y se le reconoció un nuevo título nobiliario, el condado - elevado a marquesado - de Basto, por herencia familiar ${ }^{45}$. Destacado erudito, demostraría sus dotes histórico-literarias al amparar la reedición del Jardín de Apolo, sobre los textos recopilados por

40 SOUSA, 1646: 610.

${ }^{41}$ SOUSA, 1678: 388-389.

42 SOUSA, 1975. MARTÍNEZ HERNÁNDEZ, 2012.

${ }^{43}$ CUNHA, 2015.

44 ALBUQUERQUE COELHO, 1654. VALLADARES, 2006: 41-44. Las motivaciones del círculo de Soares contra el conde de Pernambuco se recopilaron en el libelo Razones por las que no se debe imprimir la historia que trata de las guerras de Pernambuco. BOUZA, 2018: 25.

${ }_{45}$ FREIRE, 1973: 215-216. Decreto de Felipe IV a Fernando de Borja (Madrid, 8 de enero de 1647), AGP, Personal, caja 826, expediente 11. 
Melchior de Fonseca Almeida ${ }^{46}$, y, sobre todo, con la escritura de los dos compendios sobre las coronas ibéricas iniciadas con sendos milagros: las batallas de Covadonga y Ourique.

Por su parte, Jerónimo de Ataíde descendía de una ilustre familia con importantes servicios a los Felipes - su progenitor fue uno de los gobernadores del reino-, a los que se sumó una incontrastable lealtad tras los sucesos de diciembre de $1640^{47}$. El premio de Felipe IV se ilustró en su titulación como marqués de Colares (1643) y la mayordomía mayor de la reina Isabel de Borbón. Posteriormente, formó parte del Consejo de Portugal en la corte española, reactivado en 1658. La historiografía más reciente ha aportado interesantes estudios y comentarios sobre su persona y círculo han aportado luz sobre los comportamientos políticos y culturales del personaje, sumamente celoso de su proyección personal, aparte de sujeto de «noticiosa erudición». De hecho, Colares articularía una tupida red de corresponsales epistolares, entre los que descollaron Baltasar Gracián, el cronista aragonés Juan Francisco Andrés de Uztarroz y el luso Luís de Sousa, autor de los Anais de dom João III ${ }^{48}$.

Ataíde y Albuquerque Coelho eran, por tanto, significados aristócratas que debían a los Habsburgo su estatus social y su mantenimiento económico fuera de su patria rebelde. El mencionado otium que disfrutaban forzosamente en Madrid les convertiría en conspicuos escritores políticos. Dada la preeminencia de la Historia en la formación nobiliaria y en las posibilidades prácticas que se abrían de su ejercicio como memorialistas o cronistas sin título oficial para la justificación de intereses y peticiones particulares, ambos señores no cejaron en componer sus obras ${ }^{49}$. Estas podían verse mediatizadas por sus experiencias personales, por los vínculos de sangre con otros nobles o soberanos de las antiguas dinastías ibéricas e, incluso, por la posibilidad de hacer circular sus escritos como manuscritos volantes dentro de sus círculos cortesanos.

La unión de afinidades entre la dinastía y sus vasallos franqueaba la direccionalidad de las obras cronísticas con el objetivo de justificar el imperio de los Austrias y el origen fundacional del mismo en Pelayo. El caudillo del siglo VIII aparecía en los compendios y tablas de Colares y Pernambuco como el incipit de la serie de monarcas que, en una línea recta ininterrumpida, culminaban en Felipe IV y su hijo Baltasar Carlos. Los dos señores no harían una historia lejana a los protagonistas, pues ambos eran destacados miembros de sus casas reales -Ataíde también gobernaría la del príncipe de Asturias durante su

46 ALMEIDA, 1655.

47 Sobre el papel político jugado por Jerónimo de Ataíde durante la última década de dominio filipino sobre Portugal, véase SCHAUB, 2001: 165, 230-235.

${ }^{48}$ El vínculo entre Gracián y Colares, aparte de los mencionados historiógrafos, se desgrana en BOUZA, 2008: 68-71.

${ }^{49}$ Una visión global en torno a la composición de Historia y el valor social y político de la misma durante la alta Modernidad se halla en KAGAN, 2010. 
postrer viaje a Pamplona y Zaragoza en 1646 - y podrían medrar frente a otros compatriotas émulos o de mayor representatividad cortesana. Por este motivo, cabría preguntarse acerca de la labor formativa o propagandística respecto a la continuidad del cuerpo místico de la Corona y la pervivencia de su naturaleza protegida por la divinidad, tal y como se había manifestado en el combate de Covadonga.

El afán moralizante de las obras arrancaba con la pérdida de España provocada por los pecados de los últimos soberanos godos, Witiza y Rodrigo. Este trasunto no podía dejar de ser sensible al espacio público de debate madrileño de la década de 1640. Alterado con el curso de los conflictos contra Francia y por las sediciones y revueltas generalizadas, así como por el curso del valimiento de Olivares y los comportamientos privados del rey Felipe, se hallaban analogías. El uso de sermones y tratados teológicos como arma arrojadiza en las pugnas cortesanas había alcanzado su cénit en la cuaresma de 1637, cuando el valido tachara a los religiosos de erigirse en el púlpito como «los caudillos de todas las sediciones del mundo», provocando «el descrédito del gobierno, deshonra de los buenos ministros y vasallos de Vuestra Majestad $»^{50}$.

Años más tarde, el panorama escatológico que desarrollara el seglar marqués de Colares en sus semblanzas de los reyes de Asturias tomaba dos puntos referenciales: el desastre visigodo ante las huestes musulmanas en Guadalete y la victoria en la cueva asturiana ${ }^{51}$. La pérdida del favor divino por culpa de los vicios de los monarcas era causante de la ruina del reino entero y de la fe católica. Según el portugués, el fracaso solo pudo subvenirse gracias a un milagro generado por la misericordia divina, circunscrito en una roca que sirviese para resucitar el culto y fuese amparo salutífero por «la poderosa mano de Dios». Como si de un mesías regio se tratara, Pelayo, un soberano santo y no inconstante ni violento como el rey Rodrigo, había de restaurar la monarquía perdida de los godos. La España descrita por Colares para narrar sus historias sería «cabeça de todo Europa» ya en el siglo VIII, tal y como sucedía a la hora de tomar la pluma, cuando sus provincias «rinden vassallaje al mayor monarcha del mundo, el rey don Felipe $4^{\circ}$ el Grande, que vino a heredallas juntas y unidas». Así, una idéntica España bajo Pelayo y el Rey Planeta no podía doblegarse a sus oponentes, ni conformarse con una subyugación berberisca. La esencia del reino radicaba en su confesionalismo, idéntico en los tiempos pelagianos y en los de su descendiente, cuya obligación era defender tal «centro de la Christiandad».

${ }^{50}$ Consulta del conde-duque de Olivares a Felipe IV (Madrid, 24 de octubre de 1637), en ELLIOTT y PEÑA, 2013, I: 339. Quede patente mi agradecimiento a Fernando Negredo del Cerro por advertirme de esta problemática olivarista.

${ }^{51}$ Para facilitar la lectura se obvia la repetición de referencias textuales, provenientes de Jerónimo de Ataíde, Semblanzas de los reyes de Asturias, mss., Madrid, post. 1643, BA, 51-IX12: $126 \mathrm{r}-130 \mathrm{v}$. 
Pelayo no era un mero caudillo levantisco, sino «rey de sus obediensias», las cuales constituían las únicas «possesiones» de la investidura real. La soberanía de afectos le hizo erigirse en protector de los cristianos expatriados a las montañas de Asturias y, a la vez, en fiero enemigo de musulmanes y apóstatas. La doble lectura de Colares, contraponiendo de forma sutil los sucesos de Pelayo con los de Felipe IV, era evidente. Se trataba de un espejo de Historia en el que el exiliado fidalgo parecía asimilar a los refugiados en los montes norteños con aquellos paisanos huidos del régimen bragancista y radicados en la patria común de Madrid. Frente a ellos aparecía el retrato psicológico del prelado colaboracionista Oppas, hermano del rey Witiza y autor de un discurso político - derivado de las narraciones apócrifas de la cronística medieval- fundamentado en la temeridad política, la pertinacia, la imposibilidad de resistencia ante un dominio superior y en la simbiosis del rey muerto al rey desposeído. Esta pléyade de categorías maquiavélicas se oponía a la imagen de Pelayo, rey de la ocasión para el prelado traidor, pues contrabalancearía los efectos de la fuerza y la violencia de Oppas y el general ismaelita Abrahen. Su definición le hacía no «pastor de los rebaños de Dios», sino «carnisero [sic] lobo de sus ovejas», renegado de su religión, desleal a su señor natural y «sangriento verdugo»» de España. La utilización metafórica de personajes históricos hacía trascender la mera semblanza biográfica para que Colares se adentrase en la crítica política y la censura hacia quienes habían contravenido la obediencia debida al presente rey de España. No sería peregrino afirmar cómo este arquetipo de maldad, Oppas, pudiera asemejarse a un personaje coetáneo, el arzobispo de Lisboa, Rodrigo da Cunha, instigador de los castigos contra la conjura del duque de Caminha en 1641 y firme baluarte eclesiástico de João IV ${ }^{52}$. De hecho, revisando los sujetos del nuevo gobierno lisboeta, el propio conde-duque de Olivares había descrito al arzobispo como «segundo don Opas, también hijo de traidor, clérigo virtuoso hasta ahora, teólogo bronco, persona sin ingenio, tenaz y ambiciosor ${ }^{53}$. Describir los sucesos de Covadonga no solo permitía proyectar la representación providencialista de una renacida monarquía, sino también saldar cuentas entre enemigos íntimos de las elites portuguesas.

La semblanza pelagiana de Jerónimo de Ataíde situaba al católico monarca al mismo nivel que los grandes héroes bíblicos que habían actuado como eje de transmisión de la voluntad divina y el recorrido vital del pueblo elegido por

${ }^{52}$ Sobre el papel crucial del prelado en los acontecimientos de 1640-1641, véase VALLADARES, 1998: 39-40. Pocos minutos después del asesinato del secretario Vasconcelos, los fidalgos conjurados el 1 de diciembre de 1640 se encaminaron a casa del arzobispo Cunha, quien presidió, con la cruz, una procesión de expiación por Lisboa. «Al poco, la mano de Cristo crucificado se separó del madero, lo que fue considerado como un signo de la anuencia de Dios»». LÓPEZ-SALAZAR CODES, 2011: 83.

${ }_{53}$ Carta del conde-duque de Olivares al marqués Virgilio Malvezzi (Madrid, 10 de marzo de 1641), en ELLIOTT y PEÑA, 2013, I: 373. 
Dios para expandir su mensaje. El rey gótico se asimiló a la imagen de nuevo Moisés, de un Jonás liberado de sus trances peregrinos o del resucitado Lázaro. Para el marqués, el rey de obediencias liberaría de la opresión a sus súbditos. A fin y al cabo, fuesen visigodos o portugueses, «su pueblo somos, no menos oprimidos». El logro de la liberación, de la restauración del orden político tradicional, de la soberanía, no debería ir acompañado de intentos por ampliar el dominio temporal de la monarquía. El objetivo de Pelayo tras el éxito de Covadonga pasaba por reforzar el carácter confesional de la resucitada corona española y su misión última era la defensa de la fe católica y su difusión. Como advertencia, dom Jerónimo incluiría un postrer apotegma:

Que los mayores imperios ninguno aspire a intentos de ensanchar posesiones con la vitoria, sino de restituir a Dios las suyas que están usurpadas y propagar su lei evangélica.

En la década de tribulación por excelencia para la Monarquía de España, el recurso al rey Pelayo no se había mostrado baladí. Un reducido núcleo de fidalgos reforzó la recuperación, compleja y divergente, de su figura mediante la interacción entre un pasado casi legendario con la realidad política de una estructura universalista en crisis. Para quienes habían abandonado su patria y beneficios, recordar al vencedor de Covadonga y proyectar la vigencia de su imagen hacia Felipe IV supondría la externalización de una obediencia heredada a su señor natural y a la causa católica frente a sus enemigos. Evocar el pasado pelagiano podía revertir de forma decisiva la desmembración de España que se estaba materializando con las escisiones de Portugal y Cataluña, las sediciones aristocráticas de Medina Sidonia en Andalucía y de Híjar en Aragón, los oscuros movimientos en Navarra en torno a Miguel de Iturbide, las sublevaciones de Palermo y Nápoles, y las calamidades bélicas en los Países Bajos meridionales ante los avances de neerlandeses y franceses ${ }^{54}$.

Uno de los actores principales de la turbulenta década de 1640, portugués exiliado y antiguo gobernador general de Flandes, fue Francisco de Melo (15971651). Conde de Assumar en tierras lusas, marqués de Vellisca (tras serlo infructuosamente de Torrelaguna) y vizconde de Saceda en Castilla, don Francisco fungía dignidades palatinas y cargos políticos de la más alta graduación. Gentilhombre de la Cámara, consejero de Estado y de Guerra, virrey de Aragón y provisto como capitán general del ejército de Cataluña, en 1648 fue el destinatario de un elogioso encomio político ${ }^{55}$. Dicho año, el doctor Giuseppe

${ }^{54}$ Sobre estas problemáticas todavía es preciso referir el esfuerzo de síntesis de los estudios recopilados en VV. AA., 1992.

${ }_{55}$ A falta de una biografía actualizada sobre este poliédrico militar, ministro y diplomático portugués, véase la semblanza de GONZÁLEZ PALENCIA, 115/2 (1944): 209-257. 
Micheli Márquez, barón de San Demetrio y vicecanciller de la Orden Constantiniana de San Jorge, daba a las prensas madrileñas de Juan Sánchez la estampa de El fénix católico don Pelayo, el restaurador, renacido de las cenizas del rey Witiza y don Rodrigo, destruidores de España, incluyendo dos grabados, el del monarca biografiado y el del propio autor, este último por Juan de Noort ${ }^{56}$. El togado jenizaro hispano-siciliano, prolífico autor de historias y tratados nobiliarios, había logrado la publicación gracias a la inversión del librero portugués Pedro Coelho, quien debió sugerir el encaminamiento de su dedicatoria a Melo. En ella, insertó un tradicional elenco de servicios militares y diplomáticos en el Sacro Imperio, Italia y los Países Bajos. «Padre general de todos», afamado y triunfante en sus empresas - sin hacerse mención a la estratégica derrota ante Rocroi-, Micheli no ahorró epítetos para tratarle como nuevo Teodosio, al juntar letras y armas, o en recordar su ascendencia de la Casa Real de Portugal. Unas Genealogías imperiales y reales agregadas al final del tratado daban fe de los supuestos orígenes de Melo, vástago de los reyes de León, Sicilia y Nápoles, Aragón, Navarra, Castilla, Portugal, Francia, Inglaterra o los propios césares del Sacro Imperio. Su sangre y virtudes coadyuvarían al triunfo de su señor natural, el rey Felipe, contra sus enemigos franceses y catalanes. Francisco de Melo, fiel vasallo, experimentado militar y prudente ministro, estaría destinado al buen logro de su misión ${ }^{57}$.

La vinculación de un ilustre fidalgo a la figura de Pelayo se glosó no en los escuetos paratextos de Micheli Márquez, sino en el grabado de portada donde los escudos de Melo y del propio autor se disponían en paralelo como soportes de la efigie del monarca victorioso. La asimilación del exiliado luso con el primer soberano de las Asturias se hacía paradigmática y evidenciaba la continuidad de una práctica que, de forma autónoma y paralela, ya habían desarrollado los mencionados compatriotas del dedicatario. El conde de Assumar no fue el único de los portugueses felipistas que, en la esperanza de sus actos, serían actores de un paralelismo restaurador. Años más tarde, una obra teatral del Colegio jesuita de Bruselas proyectará la figura del $d u x$ de Lusitania, Claudio, para tejer vínculos entre este prohombre hispanorromano al servicio del católico godo Recaredo y Francisco de Moura Corte Real, tercer marqués de Castelo Rodrigo y gobernador general de Flandes, en tanto vencedor de conspiradores, traidores y enemigos externos de su señor ${ }^{58}$. En el caso de Melo, la asimilación de dos procesos completamente separados, la reconquista de

${ }^{56}$ MICHELI MÁRQUEZ, 1648. Existen dos ediciones facsimilares, la primera con prólogo de Agustín Hevia Ballina en 1980, y otra en 2007 sin paratextos actuales.

57 Al excelentíssimo señor don Francisco de Melo y Genealogías imperiales y reales de las quales tiene origen la excelentíssima casa de don Francisco de Melo, en MICHELI MÁRQUEZ, 1648.

${ }^{58}$ QUIRÓS ROSADO, 108 (2010): 152-189. 
Cataluña y la memoria pelagiana, se aunarían ahora de forma intrínseca bajo el topos político de la restauración como proyecto supremo del Rey Católico.

El volumen del doctor Micheli ya debía estar ultimado en la primavera de 1647, cuando pasó todos los trámites censores del Consejo de Castilla, del vicario de Madrid y de sendos evaluadores, fray Diego Niseno y Gil González Dávila, cronista del rey. La razón de ser del libro, al igual que los originales del marqués de Colares, tenía un sustrato político y moralizante, basculando sobre dos conceptos sobradamente utilizados por los autores del momento: pérdida y restauración $n^{59}$. Su utilización interesada de la memoria de Pelayo era difícil de catalogar en los métodos de historiar el pasado ibérico, aunque - como ha apuntado Martín Ríos Saloma - el doctor siciliano haría de ella una «actualización barroca del discurso» originado y popularizado por Morales y sus lectores. Los sucesos, reales o ficticios, no dejaban de ser la tramoya de un «theatro trágico» o de «scenas alegres» de un consumo meramente político. Poco importaba a Micheli la peligrosidad de escribir, según su testimonio, acerca de sucesos antiguos «de las cosas que no se han visto». Cual nuevo Platón (sic) y Jenofonte, el jenizaro hacía gala de fundamentarse en la verdad y la virtud tomadas como acero y escudo para combatir en el Teatro de la Corte en favor de «la grandeza del Imperio Hispano y la inmortalidad de sus moradores». Frente al esfuerzo realizado en paralelo por Diego de Saavedra Fajardo en su Corona góthica, exitosa a la hora de articular una narración crítica sobre el pasado germánico de España y una línea discursiva sobre los efectos del buen (y mal) gobierno, don Giuseppe articuló un híbrido novelesco y confesional en pro de la restauración monárquica ${ }^{60}$. Para ello, recurriría a mistificaciones, oraciones, cartas y discursos apócrifos, aparte de un uso interesado de cronistas medievales castellanos y autores del siglo XVI y coetáneos, desde Morales, Garibay y Mariana hasta Vasaeus, Pinciano, Mármol, Baronio o Faria e Sousa, entre otros afamados escritores.

A través de 232 páginas, la imagen de Pelayo de Asturias se consolidaba como contrapunto a los amorales soberanos góticos precedentes: el injusto Egica, el sacrílego Witiza y el lascivo Rodrigo. Todos ellos fueron artífices de tributos que provocaron la desaparición del reino. El soberano asturiano, por contra, se erigía como «único Atlante y principio de la mayor monarquía del Orbe», la de su descendiente Felipe $\mathrm{IV}^{61}$. El símil entre ambos, articulado por Ataíde y Albuquerque Coelho de forma soslayada, aquí tomaría cuerpo. El rey de España, «Grande y Pío en el campidolio de la eternidad», había de emerger de los actos de sus adversarios por medio de la prudencia, el mando, la fama y

\footnotetext{
59 MICHELI MÁRQUEZ, 1648: 1-7.

${ }^{60}$ Sobre el goticismo de Saavedra Fajardo, véase SANMARTÍN PARDO, 17 (2007): 201-221.

${ }^{61}$ La glorificación escatológica de Felipe IV aparece desarrollada en MICHELI MÁRQUEZ, 1648: 3.
} 
la constancia ante las adversidades de su corona. La monarquía se transmutaba, como sucediese tras la catástrofe de Guadalete, en una «humilde caña, combatida de furiosos araucanes, reciviendo aora el uno y el otro golpe, siempre se alza verde y entera». El Sol hispano debía coger el estandarte de la Fe, convertido en cetro real, para abatir finalmente a sus enemigos. Este triunfo que se vaticinaba ante el espejo de la Historia haría más llevadera la inestable fortuna, tinieblas y humillaciones de las que Felipe IV, sus españoles y las Águilas austriacas saldrían airosas.

\title{
UN EPÍLOgO A TINTA Y BURIL. LA CREACIÓN ICÓNICA DE COVADONGA
}

\begin{abstract}
Después de aquella lamentable pérdida de España, teniendo el universal imperio y dominio de ella los godos, tomaron las armas contra los sarracenos las reliquias de los christianos que avían quedado en diversas partes; y primero que todos los que se hallaron en las Asturias con el famoso y valeroso infante don Pelayo; y empeçando a obrar maravillas en su restauración, sucedió que de la suerte que de las ruynas de un grande edificio se fabrican otros menores: así se fueron çanjando y levantando muchos nuevos señoríos en España, debaxo de diversos príncipes, leyes, costumbres y lenguas; porque como separadamente cada parte trabajaba por recuperar la libertad perdida, el fruto que cogía le quería para sí, sin intervención de la otra (que siempre fue difícil admitir compañía al dominio, a la gloria y al provecho), conque disponían y distribuían lo que se adquiría según mejor les parecía para su conservación y aumento ${ }^{62}$.
\end{abstract}

La literatura pelagiana, eclosionada de la mano de fidalgos exiliados o de controvertidos autores a su servicio o al de la propia Corona, sentó los fundamentos de una relectura política de la restauración de la monarquía. Un proceso ambivalente este que, como infería el presbítero luso Pedro Valençuela en su Portugal unido y separado (1659), había comenzado a desarrollarse sobre las ruinas del dominio gótico sobre España, gracias a las «reliquias de los christianos» acaudillados por Pelayo en Asturias y otros príncipes en el resto de la vieja Iberia, y cuya interpretación historiográfica se tiñó de tintes presentistas. El fondo de los tratados y opúsculos aducía la esperanza de que la intervención divina obrase el milagro de la conservación del poder de Felipe IV, derrotando a sus rivales franceses, suecos y neerlandeses, y reintegrando a sus dominios los territorios perdidos en Cataluña y Portugal. Pese a la naturaleza privada o inédita de los manuscritos del marqués de Colares y del conde de Pernambuco, el éxito divulgador de las de Rodrigo Mendes Silva y Giuseppe Micheli Márquez, y la inserción de breves referencias en otras obras u opúsculos, tales referencias denotaron el resurgimiento de la

62 VALENÇUELA, 1659: 1-2.

Hispania, 2020, vol. LXXX, n. ${ }^{\circ}$ 266, septiembre-diciembre, págs. 689-720, ISSN: 0018-2141, e-ISSN: 1988-8368 https://doi.org/10.3989/hispania.2020.018 
figura política de Pelayo hasta convertirse en un argumento reiterativo en la cultura política hispana de la segunda mitad del siglo XVII ${ }^{63}$.

El fénix católico de Micheli, una obra plenamente confesional y articulada en torno al factor del catolicismo militante, proveyó a la emblemática de su tiempo de un canon de Pelayo de Asturias no tanto por su argumentario escrito, sino en la construcción imaginaria (figura 1$)^{64}$.

Un impresor madrileño anónimo desplegó en la portada del tratado un modelo del príncipe triunfante enarbolando el estandarte-cetro de la Cruz. Como un nuevo Constantino - imagen, a su vez, central en la razón de ser de la Orden de San Jorge_-, el modelo propugnado por el barón de San Demetrio incluiría dos nuevas referencias visuales: por un lado, la procesión del Sacramento poniendo en fuga las banderas sarracenas; por el otro, la llegada de la comitiva cristiana a la Cueva Santa de Covadonga, apenas esbozada por el grabador en un paisaje de montañas y árboles agrestes.

Paradigmáticamente, el santuario mariano, construido en tiempos de Alfonso I de Asturias, había obtenido recientemente el favor de Felipe IV para anexionarse el beneficio de La Mota y el priorato de San Nicolás del Camino. Los diplomáticos españoles en Roma —entre ellos, Manuel de Moura, segundo marqués de Castelo Rodrigo - se encargaron de negociar con los sucesivos pontífices el asenso de la gracia entre 1635 y $1659^{65}$. La inclusión de estas rentas en los bienes de la abadía asturiana supondría un alivio para su maltrecha hacienda. Según los registros de la Junta General del Principado, en su reunión de 8 de julio de 1646, sus problemas financieros se habían acrecentado con motivo de la visita ad limina realizada a la Santa Casa por el obispo de Oviedo, Bernardo Caballero, quien no escatimó en reclamar los alcances ejecutados contra su abad. La oportuna intervención de los junteros asturianos limitó el alcance de la crisis económica de Covadonga, al menos temporalmente ${ }^{66}$. Años después, la Junta y su Diputación proseguirían la estela de ayudas pecuniarias, bien por la vía de «socorro para ayuda de los reparos de la yglesia», en especial su escalera - seis mil reales de vellón como limosna en 1664, que no se pagaron hasta diez años

${ }^{63}$ GIL PUJOL, 2016: 257.

${ }^{64}$ Esta afirmación se contrapone - o complementa - a la teoría alternativa de Ríos Saloma, por la que el Pelayo retratado por Micheli Márquez apelaba a una «nueva conciencia identitaria» frente a «la identificación colectiva basada en el elemento religioso». La propia santificación del rey asturiano por el jenizaro falsario denota la vigencia del marco confesional como principal motor de sus argumentos. RÍOS SALOMA, 2011: 101.

${ }_{65}$ Despachos de Felipe IV (Madrid, 18 de julio de 1635 y 30 de diciembre de 1644), AHNOB, Osuna, caja 1978, documento 29. Despacho de Felipe IV (Madrid, 1 de febrero de 1659), AHN, Ministerio de Asuntos Exteriores, Santa Sede, legajo 97, ff. 109r-v.

${ }_{66}$ Acuerdo de la Junta General del Principado de Asturias (Oviedo, 8 de julio de 1646), en VELASCO ROZADO y TUÑÓN BÁRZANA, 2000, II: 445. 
Figura 1. Pelayo de Asturias, autor desconocido, frontispicio o portada calcográfica de la obra de Micheli Márquez, Giuseppe, El fénix católico don Pelayo el Restaurador. Renacido de las cenizas del rey Witiza y don Rodrigo, destruidores de España, Madrid, por Juan Sánchez, 1648

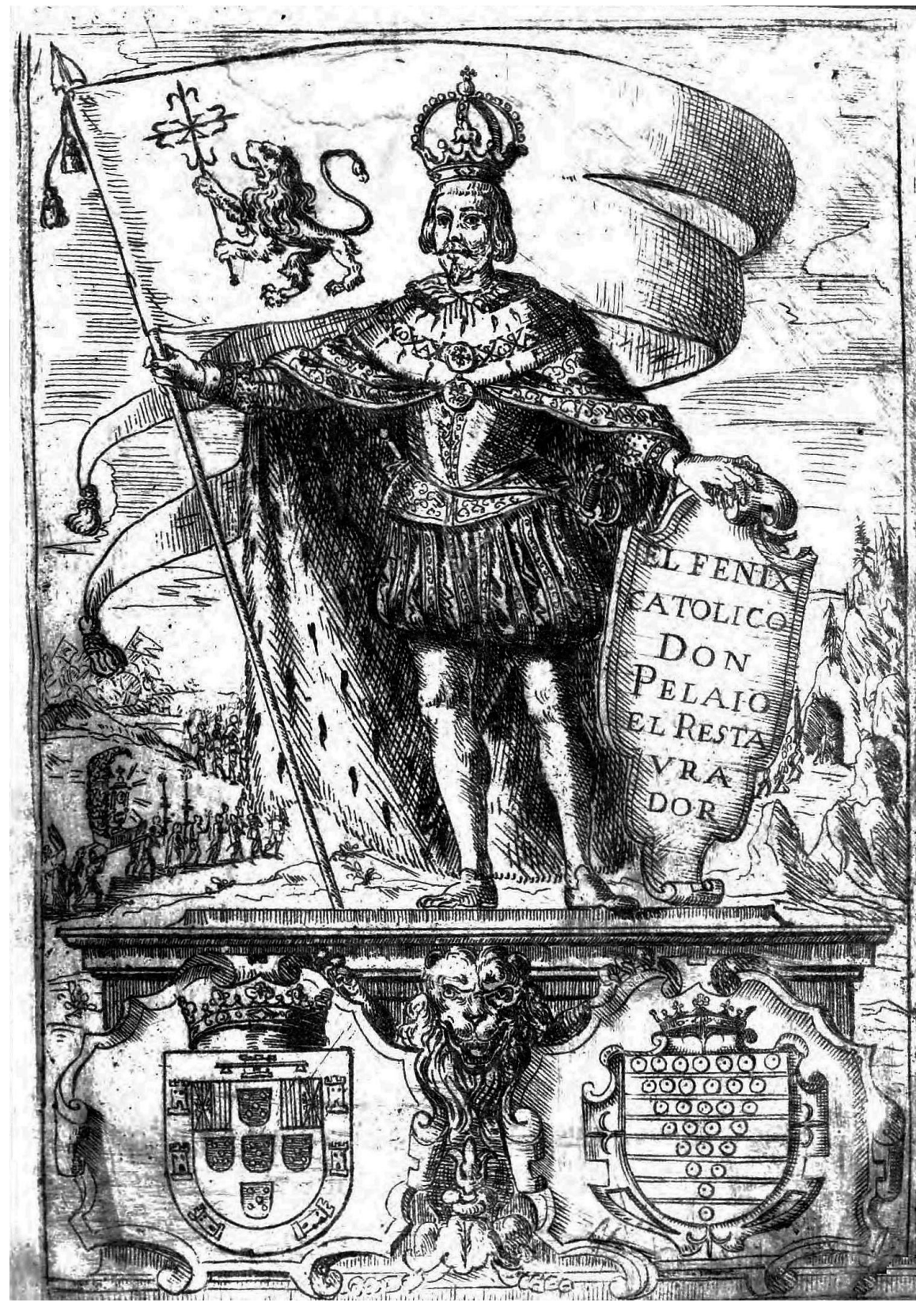

Hispania, 2020, vol. LXXX, n. ${ }^{\circ}$ 266, septiembre-diciembre, págs. 689-720, ISSN: 0018-2141, e-ISSN: 1988-8368 https://doi.org/10.3989/hispania.2020.018 
después-, bien con la concesión de rentas efectivas sobre los efectos del arrendador de la sal del Principado ${ }^{67}$.

Mientras se solucionaba la quiebra económica de Santa María de Covadonga por medio del patronato regio, la protección episcopal y la liberalidad de la corporación asturiana, en la corte de Madrid se publicó un nuevo tratado pelagiano: España restaurada por la Cruz. El voluminoso escrito teológico de Juan de la Portilla Duque, impreso gracias a la dadivosidad de las Cortes de Castilla, ahondaba en las apariciones milagrosas de la cruz de Cristo en pro de los españoles desde los lejanos tiempos de Pelayo y Alfonso I. Nuevamente, la proyección providencialista del reino de Asturias volvía a estar presente en la literatura y los debates confesionales madrileños tras cerca de un decenio sin producciones sobre la temática. La primera parte del libro centró sus investigaciones en las apariciones crucíferas al infante gótico con los dos padres del Imperio Cristiano de Roma: Constantino y Teodosio. Pelayo, restaurador de España, daría inicio a la definitiva identificación de la monarquía (re)naciente con el credo católico. El símbolo de la unión sería exquisitamente descrito por Portilla:

Lo primero, esta Santa Cruz vista en el cielo o en el ayre es semejante a la antigua de Calatrava, la que hasta oy estamos venerando en esta Religión Militar y Sagrada. Lo segundo, aparecióse vestida de resplandores de fuego. Lo tercero, acompañada de coros angélicos; los que con celestiales hymnos y vozes vencedoras le anuncian al Santo Rey ha de ser triunfador, prometiéndole in hoc signo vinces, con esta señal vencerás. Lo quarto, la parte inferior a la mano diestra señala a Covadonga; caverna santa que sirvió como de cuna, en donde al infante Pelayo la gran misericordia de Dios le dio los pechos de su Cruz; y el que está puesto de rodillas a las espaldas del rey adorando la Cruz es el fundador de la noble familia de los Casos. Lo quinto, a la mano siniestra verás los sarracenos, que despidiendo de su arco las saetas, se buelven contra ellos mismos; que puestos en huýda espantosa, se precipitan y despeñan ${ }^{68}$.

La explicación retrataba en tipos móviles el grabado que Portilla agregó a su tratado (figura 2). El manejo del buril corrió a cargo de Diego de Obregón, uno de los más solicitados grabadores de la corte de Felipe IV, quien dispuso para la imprenta un dibujo original de Alonso Cano. La división formal de la imagen muestra al lector dos ámbitos. El superior, angélico, circunda la llameante cruz calatrava y el lema constantiniano por excelencia. Debajo de las oscuras nubes, el grupo de soldados cristianos se agolpa a las puertas de la Cueva Santa, mostrando sus lanzas enhiestas y a Pelayo - como un joven imberbe y coronado- y su

${ }^{67}$ Acuerdos de la Junta General del Principado de Asturias (Oviedo, 4 de noviembre de 1660 y 8 de diciembre de 1669), en VELASCO ROZADO y TUÑÓN BÁRZANA, 2002, III: 152, 420. Acuerdos de la Junta General del Principado de Asturias (Oviedo, 23 de diciembre de 1672 y 8 de febrero de 1674) y Quenta que se tomó a don Alonso Carreño (Oviedo, 17 de octubre de 1674), en VELASCO ROZADO y TUÑÓN BÁRZANA, 2004, IV: 110, 421, 466, 519.

${ }^{68}$ PORTILLA DUQUE, 1661: 2r. 
Figura 2. Alonso Cano (dibujo) y Diego de Obregón (grabador), Batalla de Covadonga, en Portilla Duque, Juan de la, España restaurada por la Cruz, Madrid, en la imprenta de Domingo García Morrás, 1661, folio 1v

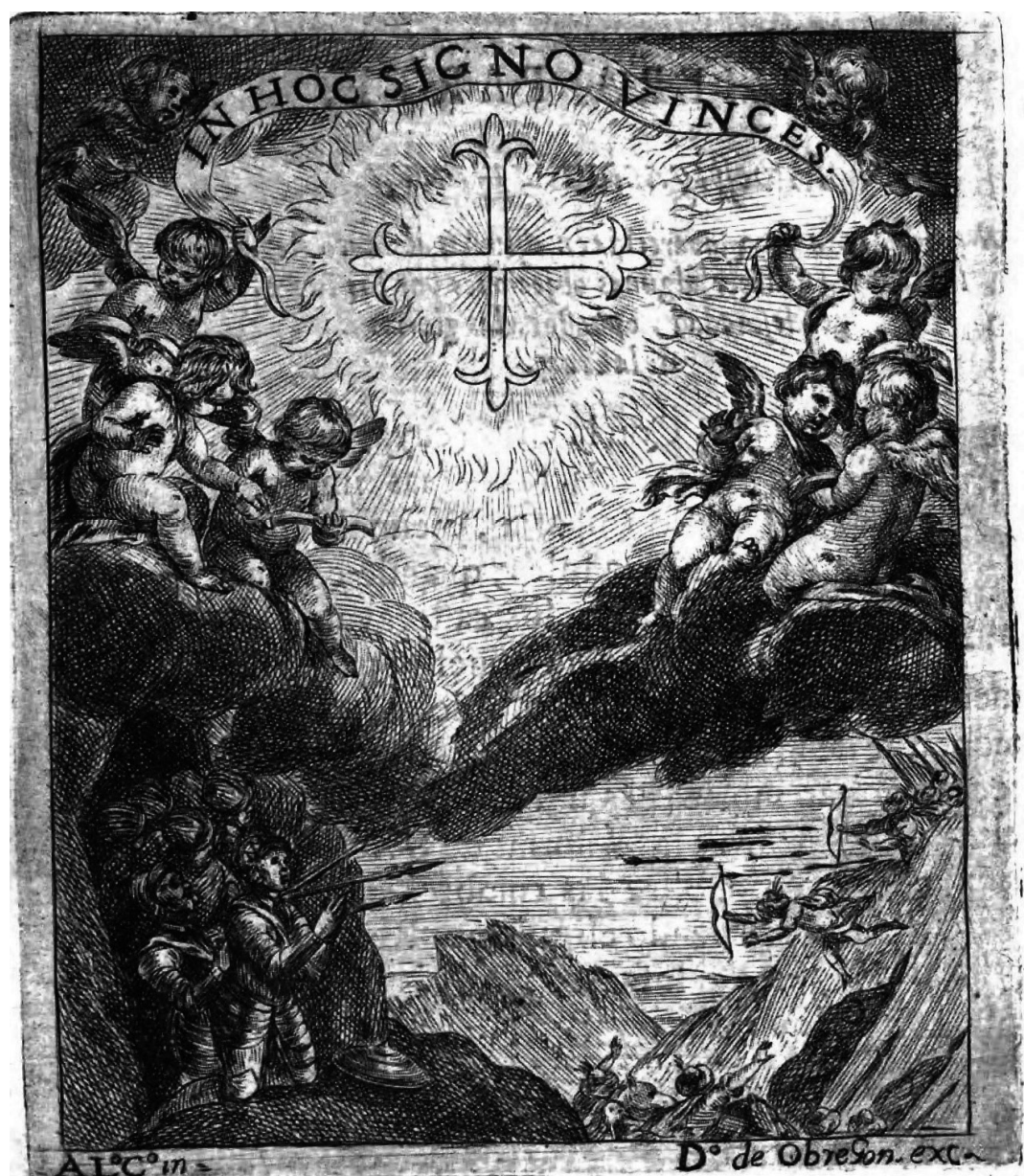

lugarteniente asturiano, de apellido Caso, dirigiendo sus oraciones al Cielo. Frente a ellos, por debajo de los roquedos, las tropas ismaelitas comienzan la fuga, cayendo entre las rocas, mientras otros ven dirigirse hacia ellos sus propias flechas ${ }^{69}$.

Con los trazos de Alonso Cano, y a diferencia de la narración pintada del libro de Micheli Márquez, la iconografía de 1661 denotó la fijación de un modelo

${ }^{69}$ GONZÁLEZ SANTOS, 2004. Un dibujo preparatorio del grabado se conserva en Museo Nacional del Prado, D000050. Quede patente mi agradecimiento a Juan María Cruz Yábar (Museo Arqueológico Nacional) por tales indicaciones. 
representativo de los sucesos de Covadonga para sus coetáneos y para el resto de la Edad Moderna. La vivacidad de la composición bélica bien pudiera acompañar a los versos latinos que el conde de Santisteban diese a la imprenta un año atrás o a la comedia de capa y espada, enredos y batallas legendarias que Juan Bautista Diamante estrenase hacia 1662 con el título El restaurador de Asturias:

Vanse, y suena ruido de batalla. / Dentro. La Cruz de Christo. / Dentro Mahomad. Qué ossados / la cueba embisten los moros! / Dentro Hamete. Pero sonior, morir tantos, / que como moscas caer. / Dentro. Huyamos, moros, huyamos, / que contra nosotros buelven / las flechas que disparamos. / Dentro Alchama. Qué hacéis, africanos nobles. / Salen por la puerta derecha los moros, algunos ensangrentados los rostros, y flechas atravessadas por diversas partes ${ }^{70}$.

El curso de los relatos, entre ellos el de este epígono calderoniano hijo de padre grecosiciliano y madre portuguesa, llevaría a su máxima mistificación la historia del primer soberano de Asturias. Convertido en alter ego de reyes austriacos, modelo de patriarca de naciones, restaurador de monarquías decadentes e, incluso, barba de comedias teatrales, Pelayo pervivió como un sujeto paciente, maleable y complejo de la cultura política. Desde los oscuros tiempos del siglo VIII hasta la crisis de una monarquía universal como la de Felipe IV, su vigencia memorística impidió que su figura se evaporase de la memoria de las gentes. Reconvertido en el Sol de España, el rey de obediencias alumbraría por siglos los discursos sobre su mutable identidad.

\section{BibLiOgRAFÍA}

Albuquerque Coelho, Duarte de, Memorias diarias de la guerra del Brasil, por discurso de nueve años, empeçando desde el de MDCXXX, Madrid, por Diego Díaz de la Carrera, 1654.

Almeida, Melchior de Fonseca, Jardín de Apolo. Academia celebrada por diferentes ingenios, Madrid, por Julián de Paredes, 1655.

Benavides, Diego de, Horce succisiva, Lyon, Sumptibus Ioannis Coronneau, 1660.

Benigno, Francesco y Bazzano, Nicoletta (eds.), Uso e reinvenzione dell'Antico nella politica di Età Moderna, secoli XVI-XIX, Roma/Bari/Manduria, P. Lacaita, 2006.

Bouza, Fernando, «1640 perante o Estatuto de Tomar. Memória e juízo do Portugal dos Filipes», Penélope, 9-10 (Lisboa, 1993): 17-28.

Bouza, Fernando, «Entre dos reinos, una patria rebelde. Fidalgos portugueses en la monarquía hispánica después de 1640», Estudis, 20 (Valencia, 1994): 83-104.

70 DiAmanTE, s. d. Diamante, como hiciese Portilla Duque con los Caso o, años atrás, el marqués de Montebello y António Soares de Alarção respecto a los Sandoval y los Ceballos, incluyó como protagonista de Covadonga a un supuesto antepasado de la ilustre familia del duque de Estrada.

Hispania, 2020, vol. LXXX, n. ${ }^{\circ}$ 266, septiembre-diciembre, págs. 689-720, ISSN: 0018-2141, e-ISSN: 1988-8368 https://doi.org/10.3989/hispania.2020.018 
Bouza, Fernando, Papeles y opinión. Políticas de publicación en el Siglo de Oro, Madrid, CSIC, 2008.

Bouza, Fernando, Del escribano a la biblioteca. La civilización escrita europea en la alta Edad Moderna (siglos XVI-XVII), Madrid, Síntesis, 2018.

Brito, Bernardo de, Segunda parte da Monarchia Lusytana, Lisboa, por Pedro Crasbeeck, 1609.

Carbó García, Juan Ramón, «Tanto monta. Pervivencias clásicas y goticismo en las genealogías legitimadoras de los Trastámaras», en VV. AA., Humanismo y pervivencia del mundo clásico. V. Homenaje al profesor Juan Gil, Madrid, Instituto de Estudios Humanísticos, 2015, vol. IV: 1769-1783.

Cardim, Pedro, Portugal unido y separado. Felipe II, la unión de territorios y el debate sobre la condición política del Reino de Portugal, Valladolid, Universidad de Valladolid, 2014.

Carreño, Antonio, «La fuerza de las historias representadas. Lope de Vega y las alegorías del poder», en VV. AA., Estudios del teatro áureo. Texto espacio y representación, Ciudad de México, Universidad Autónoma Metropolitana, 2003: 17-47.

Castillo, Julián del, Historia de los reyes godos, Burgos, por Philippe de Junta, 1582.

Cunha, Mafalda Soares da, «Los Albuquerque Coelho, siglos XVI-XVII: prácticas sociales y retórica nobiliaria», en Giovanni Muto y Antonio Terrasa Lozano (eds.), Estrategias culturales y circulación de la nueva nobleza en Europa (1570-1707), Aranjuez, Doce Calles, 2015: 129-154.

Diamante, Juan Bautista, Comedia famosa. El restaurador de Asturias, s. 1., s. d.

Elliott, John H. y Peña, José F. de la, Memoriales y cartas del conde duque de Olivares (edición ampliada por John H. Elliott y Fernando Negredo del Cerro), Madrid, CEEH/Marcial Pons Historia, 2013, vol. I.

Fernández Albaladejo, Pablo, «Entre godos y montañeses. Avatares de una primera identidad española», Cuadernos de Alzate, 33 (Madrid/San Sebastián, 2005): 19-53.

Fernández Albaladejo, Pablo, La crisis de la monarquía, vol. IV de Historia de España (dirigida por Josep Fontana y Ramón Villares), Barcelona/Madrid, Crítica/Marcial Pons, 2009.

Ferro, Pedro Rosa, Virtude política. Uma análise das qualidades e talentos dos governantes, Lisboa, Almedina, 2017.

Floristán Imízcoz, Alfredo, «Polémicas historiográficas y confrontación de identificaciones colectivas en el siglo XVII: Navarra, Aragón y Vasconia», Pedralbes, 27 (Barcelona, 2007): 59-81.

Freire, Anselmo Braamcamp, Brasões da sala de Sintra, Lisboa, Imprensa Nacional/ Casa da Moeda, 1973, vol. II.

García García, Bernardo José, La Pax Hispanica. Política exterior del duque de Lerma, Lovaina, Leuven University Press, 1996.

Garibay, Esteban de, Los XL libros d'el Compendio Historial de las chrónicas y universal historia de todos los reynos de España, Amberes, por Christóphoro Plantino, 1571.

Geary, Patrick J., The Myth of Nations. The Medieval Origins of Europe, Princeton, Princeton University Press, 2002.

Gil Pujol, Xavier, La fábrica de la monarquía. Traza y conservación de la monarquía de España de los Reyes Católicos y los Austrias, Madrid, Real Academia de la Historia, 2016. 
González Palencia, Ángel, «Nuevas noticias biográficas de don Francisco de Melo, vencedor en Le Châtelet (1597-1651)», Boletín de la Real Academia de la Historia, 115/2 (Madrid, 1944): 209-257.

González Santos, Javier, «Apostilla a Alonso Cano, ilustrador. A propósito de la identificación de un grabado y su dibujo preparatorio realizados por Alonso Cano para ilustrar España restaurada por la Cruz (Madrid, 1661)», Boletín del Museo del Prado, 40 (Madrid, 2004): 56-63.

Guillén Berrendero, José Antonio, «Valores nobiliarios, libros y linajes: Rodrigo Méndez de Silva, un nobilista portugués en la corte de Felipe IV», Mediterranea-ricerche storiche, 30 (Palermo, abril 2014): 35-60.

Hobsbawn, Eric y Ranger, Terence, The Invention of Tradition, Cambridge, Cambridge University Press, 1983.

Jover Zamora, José María, 1635. Historia de una polémica y semblanza de una generación, Madrid, Consejo Superior de Investigaciones Científicas, 2003.

Kagan, Richard, Los cronistas y la Corona en la España medieval y moderna, Madrid, Marcial Pons Historia, 2010.

Kagan, Richard, «Las “plumas teñidas” de Felipe IV: ¿Periodismo o propaganda?», en Roger Chartier y Carmen Espejo (eds.), La aparición del periodismo en Europa. Comunicación y propaganda en el Barroco, Madrid, Marcial Pons Historia, 2012: $87-100$.

Lacerda, Bernarda Ferreira de, Hespaña libertada, Lisboa, en la officina de Pedro Crasbeeck, 1618.

Löfstedt, Bengt, «The latinist poet-viceroy of Peru and his magnum opus», Faventia, 21/1 (Barcelona, 1999): 119-137.

López, Alonso, El Pelayo, Madrid, por Luis Sánchez, 1605.

López-Salazar Codes, Ana Isabel, Inquisición y Política. El gobierno del Santo Oficio en el Portugal de los Austrias (1578-1653), Lisboa, Universidade Católica Portuguesa/Centro de Estudos de História Religiosa, 2011.

Luxán Meléndez, Santiago de, «La pervivencia del Consejo de Portugal durante la Restauración, 1640-1668», Norba, 8-9 (Cáceres, 1987-1988): 61-86.

Machado de Silva, Félix, Memorial del marqués de Montebello, s. 1., 1642.

Mariana, Juan de, Historia general de España, Toledo, por Pedro Rodríguez, 1601, tomo I.

Martínez Bermejo, Saúl, Translating Tacitus. The reception of Tacitus's works in the vernacular languages of Europe, $16^{\text {th }}-17^{\text {th }}$ centuries, Pisa, Edizioni PLUS, 2010.

Martínez Hernández, Santiago, «Aristocracia y anti-olivarismo: el proceso al marqués de Castelo Rodrigo, embajador en Roma, por sodomía y traición (1634-1635)», en José Martínez Millán, Manuel Rivero Rodríguez y Gijs Versteegen (coords.), La Corte en Europa. Política y Religión (siglos XVI-XVIII), Madrid, Polifemo, 2012, vol. II: 1147-1196.

Mesa, Cristóbal de, El Pelayo, o restauración de España. Poema heroico en octava rima, Madrid, por Juan de la Cuesta, 1607.

Micheli Márquez, Giuseppe, El fénix católico don Pelayo el Restaurador. Renacido de las cenizas del rey Witiza y don Rodrigo, destruidores de España, Madrid, por Juan Sánchez, 1648. 
Morales, Ambrosio de, Los otros dos libros, undécimo y duodécimo, de la Corónica General de España, Alcalá de Henares, en casa de Juan Yñiguez de Lequerica, 1577.

Morales, Ambrosio de, Los cinco libros postreros de la Corónica General de España, Córdoba, por Gabriel Ramos Bejarano, 1586.

Ocampo, Florián de, Los çinco libros primeros de la Crónica General de España, Medina del Campo, por Guillermo de Millis, 1553.

Portilla Duque, Juan de la, España restaurada por la Cruz, Madrid, en la imprenta de Domingo García Morrás, 1661.

Portocarrero y Guzmán, Pedro, Teatro monárquico de España (edición de Carmen Sanz Ayán), Madrid, BOE/Centro de Estudios Políticos y Constitucionales, 1998.

Prestage, Edgar, The Diplomatic Relations of Portugal with France, England, and Holland from 1640-1668, Watford, Voss \& Michael, 1925.

Quirós Rosado, Roberto, «Claudio pio, fuerte y fiel governador de Portugal. El dux Claudio de Mérida en la historiografía y publicística hispanas de la alta Modernidad», Revista de Historia Militar, 108 (Madrid, 2010): 152-189.

Quirós Rosado, Roberto, «Aspidio Rey. Joseph Pellicer de Ossau y la polémica historiográfica sobre el "indigenismo" regnícola aragonés», en Rafael Torres Sánchez (coord.), Studium, magisterium et amicitia. Homenaje al profesor Agustín González Enciso, Pamplona, Eunate, 2018: 201-211.

Révah, Israel S., «Le procès inquisitorial contre Rodrigo Méndez Silva, historiographe du roi Philippe IV», Bulletin Hispanique, 67/3-4 (Burdeos, 1965): 225-252.

Rey Castelao, Ofelia, «El peso de la herencia: la influencia de los modelos en la historiografía barroca», Pedralbes, 27 (Barcelona, 2007): 35-58.

Ríos Saloma, Martín Federico, «De la Restauración a la Reconquista: la construcción de un mito nacional (una revisión historiográfica. Siglos XVI-XIX)», En la España medieval, 28 (Madrid, 2005): 379-414.

Ríos Saloma, Martín Federico, La Reconquista: una construcción historiográfica, siglos XVI-XIX, Madrid, Marcial Pons Historia, 2011.

Sanmartín Pardo, José J., «Saavedra y el goticismo», Res publica, 17 (Madrid, 2007): 201-221.

Schaub, Jean-Frédéric, Le Portugal au temps du comte-duc d'Olivares, 1621-1640. Le conflit de jurisdictions comme exercice de la politique, Madrid, Casa de Velázquez, 2001.

Silva, Rodrigo Mendes, Catálogo real genealógico de España, Madrid, por Diego Díaz de la Carrera, 1639.

Soares de Alarção, António, Relaciones genealógicas de la Casa de los marqueses de Trocifal, condes de Torresvedras, su varonía Zevallos de Alarcón, y por la Casa y primer apellido Suárez, Madrid, por Diego Díaz de la Carrera, 1656.

Sousa, Manuel de Faria e, Nobiliario del conde de Barcelos don Pedro, hijo del rey don Dionís de Portugal, Madrid, por Alonso de Paredes, 1646.

Sousa, Manuel de Faria e, Europa portuguesa, Lisboa, a costa d'António Craesbeeck de Mello, impressor de Su Alteza, 1678.

Sousa, Manuel de Faria e, The "Fortuna" of Manuel de Faria e Sousa. An autobiography (ed. de Edward Glaser), Münster, Achendorffsche Verlagsbuchhandlung, 1975.

Sousa de Macedo, António, Flores de España, excelencias de Portugal, Lisboa, por Jorge Rodríguez, 1631. 
Sousa de Macedo, António, Lusitania liberata ab injusto Castellanorum dominio, Londres, in officina Richardi Heron, 1645.

Suárez, Diego, Tres romances de Asturias de Oviedo, Alcalá de Henares, en casa de Juan Gracián, 1607.

Terrasa Lozano, Antonio, «De la raya de Portugal a la frontera de guerra: los Mascarenhas y las prácticas nobiliarias de supervivencia política durante la guerra de la Restauração», en Bartolomé Yun Casalilla (dir.), Las Redes del Imperio. Élites sociales en la articulación de la monarquía hispánica, Madrid, Marcial Pons Historia/Universidad Pablo de Olavide, 2009: 233-258.

Valençuela, Pedro, Portugal unido y separado, Madrid, por Mateo Fernández, impresor del Rey nuestro señor, 1659.

Valladares, Rafael, Felipe IV y la restauración de Portugal, Málaga, Editorial Algazara, 1994.

Valladares, Rafael, «Sobre reyes de invierno. El diciembre portugués y los cuarenta fidalgos (o alguno menos, con otros más)», Pedralbes, 15 (Barcelona, 1995): 103-136.

Valladares, Rafael, La rebelión de Portugal. Guerra, conflicto y poderes en la monarquía hispánica (1640-1680), Valladolid, Junta de Castilla y León, 1998.

Valladares, Rafael, «Las dos guerras de Pernambuco: la armada del conde da Torre y la crisis del Portugal hispánico (1638-1641)», en José Santos Pérez y George Félix Cabral de Sousa (coords.), El desafio holandés al dominio ibérico en Brasil en el siglo XVII, Salamanca, Ediciones Universidad de Salamanca, 2006: 33-66.

Vega y Carpio, Lope de, "Comedia famosa del postrer godo de España», en Octava parte de sus comedias, con loas, entremeses y bayles, Barcelona, por Sebastián de Cormellas, 1617: 115r-136v.

Vega y Carpio, Lope de, Fiestas de Denia (introducción y texto crítico de Maria Grazia Profeti; apostillas históricas de Bernardo José García García), Florencia, Alinea Editrice, 2004.

Velasco Rozado, Josefina y Tuñón Bárzana, José (eds.), Junta General del Principado de Asturias. Actas Históricas, Oviedo, Junta General del Principado de Asturias, 2000-2004, vols. II-IV.

Viegas, António Pais, Principios del reyno de Portugal, Lisboa, por Paulo Crasbeeck, 1641.

Vila-Real, Manuel Fernandes, Anticaramuel o defença del Manifiesto del reyno de Portugal, París, en la officina de Miguel Blageart, 1643.

Villanueva López, Jesús, Política y discurso histórico en la España del siglo XVII. Las polémicas sobre los orígenes medievales de Cataluña, Alicante, Universidad de Alicante, 2004.

VV. AA., 1640. La monarquía hispánica en crisis, Barcelona, Crítica, 1992.

Yagüe de Salas, Juan, Los amantes de Teruel, epopeya trágica; con la Restauración de España por la parte de Sobrarbe, y conquista del reyno de Valencia, Valencia, por Pedro Patricio Mey, 1616.

Recibido: 11/06/2019

Aceptado: 13/10/2020

Hispania, 2020, vol. LXXX, n. ${ }^{\circ}$ 266, septiembre-diciembre, págs. 689-720, ISSN: 0018-2141, e-ISSN: 1988-8368 https://doi.org/10.3989/hispania.2020.018 